\title{
Social Entrepreneurship: Analytical Approach
}

\author{
Jehanzaib Akram \\ National University of Modern Languages, PAKISTAN
}

\section{Introduction}

Social entrepreneurs are one that are involved within making the contribution for the social, economic, cultural, and environmental betterment and development within the country. An increase trend is observed within the contribution being made by the experts within the field. In the traditional environment, charitable and other NGOS are criticized for being operating as bureaucratic organizations while public sectors are criticized for being the overstretched organizations (Zahra, Rawhouser, Bhawe, Neubam and Hayton, 2008). In such situation, social entrepreneurship is appreciated and highlighted as a source for increasing and meeting the social and economic needs of the country. The environments in which the enterprises operate are observed to directly impact over the outcomes of the research.

Social entrepreneurship is not any process or phenomena, but used for the individuals that are involved in fulfilling the social needs and demands of people rather than involved in profit generation and maximization. There are many organizations developed in the context of social entrepreneurship, but little attention has been given by the researchers for the specific discipline (Certo and Miller, 2008). There are many leftover areas, which are required to be analyzed for understanding that how effectively research is being conducted over the social entrepreneurship and what further topics are available for conducting the research.

\subsection{Problem Statement}

The problem identified is that the social enterprises are developing, but there is lack of attention given by researcher over specific sector. The problem is that social entrepreneurship is linked with many disciplines and there are many ways ofconducting the research, but there is lack of attention among researchers toward specific research area. This problem will be addressed in this research by analyzing that what kind of research is being conducted over the social entrepreneurship and what further areas are available for conducting the research over it.

\section{Literature Review}

There are various researches being conducted by the researchers for the identification of the future research topic for social entrepreneurship. The publications made by Mair\& Marti, 2006; Dacin, Dacin, \&Matear, 2010; and Harris, Sapienza\& Bowie, 2009, these three research papers are highlight recommended and appreciated for their contribution being made about the future topic for the social entrepreneurship. They moved for in-depth analysis and also detail discussion about how the social entrepreneurship can be further explored. They revealed that there are many areas and disciplines, which are linked with social entrepreneurship, but they are left and need further discussion and analysis.

Haugh (2006) stated that social entrepreneurship is required to be directed toward further implication because of the reason that there are many positive consequences and outcomes that can be acquired by the society through its implementation. Austin, Stevenson \& Wei-Skillern (2006) agreed with Haugh stated facts and further provided that the society in general can be directed toward acquiring of the positive and favorable outcomes through the development of social enterprises within the society. Haugh (2005) research was mainly focused over understanding the future agenda that how the social entrepreneurship will exist in future. She further added by analyzing the social enterprises and the non-profit organization that there are eight available themes based on which the social entrepreneurship knowledge and information will be strengthen. Haugh provided themes were based on:

Determining the social entrepreneurship scope

Analyzing the social entrepreneurship in environmental context

Understanding the opportunities available for innovation and recognition

Determining organizations' modes

Acquisition of available resources

Exploiting the available opportunities

Measurement of performance

Education for training

Learning and understanding social entrepreneurship 
These eight themes provided Haugh with an area of further research, which was done by Haugh by producing individual merit research paper over the specific research themes. These themes were considered by researchers and understanding was developed related to them for the development of social entrepreneurship. Austin, Stevenson, and Wei-Skillern (2006) were directed toward understanding and analyzing the comparison between the for-profit organization and the social enterprises. This directed toward analyzing that for-profit and not for-profit organizations are similar or different from each other. The research was focused on understanding the differences that how they will impact over the future of the specific sectors because of the differences observed among them. Based on their research being conducted, six areas were identified, which direct them for the differentiation and based on the differences, following areas for further research for social entrepreneurship were being identified:

Markets environment and structure

Mission of organizations

Capital invested within organization

People associated with them

Performance measurement and level

Context of the organization.

Based on these six differences, 28 ideas for the conduction of future research over social entrepreneurship were being identified or determined by the researchers. This directs them toward an understanding that one singlefactor can result in creating a lot of differences and also lead toward demanding of great efforts by researchers. The areas being identified are showing the important area for further research that can help in the overall development of the sector. Short, Moss, and Lumpkin (2009) also conducted the detail research over identifying the area for further detail research. It is considered as one of the most comprehensive and detail research being conducted over social entrepreneurship till this time. They were directed toward detail analysis of the available literature through conducted research for understanding that what is being already done and what is the scope or opportunities available for further research. They summarized available literature in most effective possible way.

Short, Moss, and Lumpkin (2009) provided the variant of social entrepreneurship based on the themes identified by Schendel\& Hitt. The ten variants were proposed, which were as below:

Creation of social value

Creation of opportunities for enterprises

Social enterprises directed toward risk discovering

Social enterprises innovation management

Social change effect on social enterprises

Social value creation through technology

Social innovation diffusion

Social enterprise formation process

Identifying relation among social entrepreneurship and institutes

Creation of social and economic values, simultaneously

Besides this, theories and different disciplines were highlighted, which were considered for the future research in most appropriate way. These three papers look into detail understanding that what are the available opportunity for further research and study. The researcher based on these papers revealed that there is a need of looking into the factors that are external and can create impact on social entrepreneurship. This provided the further scope for analyzing the social entrepreneurship based on the role of external factors and provided further area of research. The external factors provided the environment and market, in which the organization will be operating. Based on the available literature, it is reflected that there is a need of detail study and analysis that how the social entrepreneurship can be further studied in detail.

\section{Research Methodology}

For the conduction of research over the specific research problem, researcher has considered the conduction of the research over social entrepreneurship by looking into the research conducted over social entrepreneurship. The research paper will be collected from the online sources available for the collection of research paper database. The analysis was based on observation by collecting paper, analyzing their topic, finding data for future research, and then concluding topics for the conduction of the future research.

\section{Analysis And Discussion}

The available research paper being accessed by the researcher provided 30,000 views or aspects in which the future research can be conducted over the social entrepreneurship. The research is being conducted by 
collecting data from the field and analyzing that how they are relevant. For the conduction of the research, appendix is being attached, which is providing the highlight of themes that are made available for the conduction of the research. Overall, available papers have shown that there is a large scope available for the conduction of detail research in the field for understanding that how social entrepreneurship can be further developed.

This research paper provided two output that are linked with the raw research topic for further research and underlying themes for the conduction of the research. The raw data collected for the future research topic has provided some useful topic that can be considered for an effective understanding of the discipline for future. This can help in two ways. The one who wants to enter into the research stream can consider these topics offurther research while those already existing in different disciplines can consider these topics for the understanding that how the specific research can be conducted.

The research conducted has provided that many papers being published are not providing any further area for conducting the research over any factor. This results in creating problem as many areas are left unaddressed and problem is that young researchers are not provided with any guideline or further understanding for conducting the future research. The outside researchers have directed toward selecting their area of interest to understanding that how specific subject or field can help in the favorable outcomes for their discipline. The topic being identified by the researcher through the specific research has provided many topics that are not being discussed because of lack of interest among researchers with topic.

The further research provided the themes that were explored by the researcher by looking into the findings provided by the researchers. Many unique and different themes were observed to exist, which are surprising as they are different while many are left and are not part of discussion, which is surprising as well. The theme emerge was special corporate responsibility and ethics, which are directly linked with social enterprises as they have social objectives to be achieved. The other theme is social and economic impact, which is unique and important because it will lead toward creating direct impact on the outcomes acquired by the community involved with enterprise. The research provided that many researchers have focused on having the own social and economic environment for the social enterprises because of their different agenda from other corporate sector.

The theme that is not provided through the research being conducted is the global aspect of the social entrepreneurship. Globalization along with cross-culture and international factors is being discussed by the researchers, but did not direct toward major attention like in the topic being presented in effective methodology. This theme can exist because of the reason that they are relevant and linked with the social entrepreneurship as the world is now globally connected. The researchers conducted have found to more within culture oriented instead of looking toward the broader picture and analyzing the situation in global context. This shows that the aspects, which are more relevant toward external environment are being left for detail discussion and understanding.

These are important findings being drawn by the researcher through analyzing the available literature on broader level. They are one of the most important areas of research, which requires the further in detail discussion and analysis for understanding that how the specific problem can further develop or exist within the social entrepreneurship.

\section{Conclusion}

It is concluded from the conducted research that almost 350 social entrepreneurs research paper have been published so far, which looked into further area of conducting research on the social entrepreneurship. Based on the research conducted, 327 topics were highlighted that were categorized in to available themes for conducting the future research. These themes were: environment effect, innovation, forms of organization, Competition and collaboration, missions, individuals, stakeholders, contexts, opportunities, resources, corporate social responsibility, leadership, ethics, performance, strategies, institutes, and others. These are the available topic that can be considered for the future research. In doing this, social sector will be directed toward further development of social and economic aspects of the country. The analysis over the future research will help in understanding the academic and practical aspects by expanding the research over the social entrepreneurship work for expanding the available publication.

\section{References}

[1]. Austin, J., Stevenson, H., \& Wei-Skillern, J. 2006.Social and commercial entrepreneurship: Same, different, or both? Entrepreneurship: Theory \& Practice, 30(1): 1-22.

[2]. Certo, S. T., \& Miller, T. 2008. Social entrepreneurship: Key issues and concepts. Business Horizons, 51(4): $267-271$.

[3]. Dacin, P. A., Dacin, M. T., \&Matear, M. 2010. Social entrepreneurship: Why we don't need a new theory and how we move forward from here. Academy of Management Perspectives, 24(3): 37-57.

[4]. Harris, J. D., Sapienza, H. J., \& Bowie, N. E. 2009.Ethics and entrepreneurship. Journal of Business Venturing, 24(5): 407-418.

[5]. Haugh, H. 2006. A research agenda for social entrepreneurship. Social Enterprise Journal, 1(1): 1-12. 
[6]. Mair, J., \&Martí, I. 2006. Social entrepreneurship research: A source of explanation, prediction, and delight. Journal of World Business, 41(1): 36-44.

[7]. Short, J. C., Moss, T. W., \& Lumpkin, G. T. 2009. Research in social entrepreneurship: past contributions and future opportunities. Strategic Entrepreneurship Journal, 3(2): 161-194.

[8]. Zahra, S. A., Rawhouser, H. N., Bhawe, N., Neubaum, D. O., \&Hayton, J. C. 2008.Globalization of social entrepreneurship opportunities. Strategic Entrepreneurship Journal, 2(2): 117-131.

Table 2: Highest-Rated Research Topics*

\begin{tabular}{|c|c|c|c|c|}
\hline Author(s) & Year & Research Topic & AIS? & ADS\& \\
\hline \multirow[t]{3}{*}{$\begin{array}{l}\text { Alvord, Brown } \\
\text { \& Letts }\end{array}$} & 2004 & $\begin{array}{l}\text { How do the attributes of social innovations shape outcomes and } \\
\text { success in different contexts? }\end{array}$ & 2.67 & 4.33 \\
\hline & & $\begin{array}{l}\text { Identify the various forms that social entrepreneurial ventures may } \\
\text { take. }\end{array}$ & 3.33 & 4.00 \\
\hline & & $\begin{array}{l}\text { What contextual patterns encourage or hinder the emergence of } \\
\text { different kinds of innovations? }\end{array}$ & 3.33 & 2.67 \\
\hline \multirow{17}{*}{$\begin{array}{l}\text { Austin, } \\
\text { Stevenson \& } \\
\text { Wei-Skillern }\end{array}$} & 2006 & $\begin{array}{l}\text { To what extent are earned-income strategies successful in social } \\
\text { ventures? }\end{array}$ & 3.67 & 4.67 \\
\hline & & $\begin{array}{l}\text { What have been the effects and effectiveness of applying the } \\
\text { venture-capital approsach to social entrepreneurship? }\end{array}$ & 4.00 & 4.33 \\
\hline & & $\begin{array}{l}\text { Which contextual forces foster social innovation and } \\
\text { entrepreneurship? }\end{array}$ & 4.00 & 4.33 \\
\hline & & $\begin{array}{l}\text { What new financial instruments could be designed to overcome } \\
\text { some of the current deficiencies in the philanthropic capital } \\
\text { markets? }\end{array}$ & 3.67 & 4.33 \\
\hline & & $\begin{array}{l}\text { To what extent do eamed-income activities create tension with } \\
\text { social mission or organizational values? }\end{array}$ & 3.33 & 4.33 \\
\hline & & $\begin{array}{l}\text { What are the effects of market forces on the formation and } \\
\text { behavior of social enterprises? }\end{array}$ & 3.67 & 4.00 \\
\hline & & $\begin{array}{l}\text { In mixed markets where nonprofit and forøprofit organizations are } \\
\text { both operating, what are the relative competitive advantages, } \\
\text { disadvantages, and interactive dynamics? }\end{array}$ & 3.67 & 3.67 \\
\hline & & $\begin{array}{l}\text { What affects the extent and form of competition and collaboration } \\
\text { among social enterprises? }\end{array}$ & 3.33 & 3.67 \\
\hline & & To what extent do social enterprises correct market failure? & 3.00 & 3.67 \\
\hline & & How does the social mission affect resource mobilization? & 3.00 & 3.67 \\
\hline & & $\begin{array}{l}\text { How do country or community contextual differences change } \\
\text { contextual forces? }\end{array}$ & 3.33 & 3.33 \\
\hline & & What determines the structure of philanthropic capital markets? & 2.67 & 3.33 \\
\hline & & $\begin{array}{l}\text { How does a social entrepreneur determine the optimum mix of } \\
\text { financing sources for the social enterprise? }\end{array}$ & 2.67 & 3.33 \\
\hline & & What are the key drivers of the philanthropic capital markets? & 4.00 & 3.00 \\
\hline & & $\begin{array}{l}\text { What is the entrepreneurial process of identifying opportunities for } \\
\text { social entrepreneurship? }\end{array}$ & 3.00 & 3.00 \\
\hline & & How does the social mission affect strategy? & 3.00 & 3.00 \\
\hline & & $\begin{array}{l}\text { How do contextual forces shape opportunity creation for social } \\
\text { entrepreneurship? }\end{array}$ & 3.00 & 2.67 \\
\hline \multirow[t]{2}{*}{ Certo \& Miller } & 2008 & $\begin{array}{l}\text { What are the decision rules that philanthropic venture capitalists } \\
\text { use to select social ventures? }\end{array}$ & 3.00 & 4.33 \\
\hline & & $\begin{array}{l}\text { How do philanthropic venture capitalists influence venture } \\
\text { outcomes? }\end{array}$ & 2.67 & 4.33 \\
\hline \multirow[t]{2}{*}{ Conocy } & 2006 & $\begin{array}{l}\text { How are different types of organizational models set up to manage } \\
\text { exposure of core social services to market and business "risk," } \\
\text { taking into account different societal contexts? }\end{array}$ & 3.33 & 3.00 \\
\hline & & $\begin{array}{l}\text { Develop rigorous, empirically grounded methods for evaluating } \\
\text { structural risks to the nature of the services provided to clients. } \\
\text { the population these organizations are built to serve. }\end{array}$ & 2.67 & 2.67 \\
\hline \multirow[t]{2}{*}{$\begin{array}{l}\text { Dacin, Dacin } \\
\& \text { Matear }\end{array}$} & 2010 & $\begin{array}{l}\text { Develop a stronger understanding of social entrepreneurial failure; } \\
\text { particularly with respect to costs, benefits, loss } \& \text { grief. }\end{array}$ & 3.00 & 4.33 \\
\hline & & $\begin{array}{l}\text { What is the appropriate measure or metric of social entrepreneurial } \\
\text { success? }\end{array}$ & 2.67 & 3.33 \\
\hline
\end{tabular}




\begin{tabular}{|c|c|c|c|c|}
\hline & & $\begin{array}{l}\text { Understand the sources of failure when there are multiple missions } \\
\text { or contradictory logics at play. }\end{array}$ & 3.67 & 3.00 \\
\hline & & Develop a stronger understunding of the process of social change & 2.67 & 3.00 \\
\hline & & $\begin{array}{l}\text { based on progress made in the area of institutional change as well } \\
\text { as the role of discourse and structuration in field-level change. }\end{array}$ & & \\
\hline & & $\begin{array}{l}\text { To what exient might social entrepreneurs subjugate their social } \\
\text { mission to their profit mission in order to achieve sustainability? }\end{array}$ & 3.33 & 2.67 \\
\hline & & $\begin{array}{l}\text { Would social entrepreneurs compromise their objectives or weial } \\
\text { mission in order to suit the agendas and priorities of large funding } \\
\text { organizations, governments, and foundations? }\end{array}$ & 2.67 & 2.67 \\
\hline \multirow[t]{2}{*}{$\begin{array}{l}\text { Dann, Harnis, } \\
\text { Mort, Fry \& } \\
\text { Binney }\end{array}$} & 2007 & $\begin{array}{l}\text { Understand the effects of local legal and government contexts on } \\
\text { social value creation in an allied manner to that undertaken in } \\
\text { international business research. }\end{array}$ & 2.67 & 4.33 \\
\hline & & $\begin{array}{l}\text { Understand the effects of cultural contexts an successes and } \\
\text { failures in social entrepreneurship. }\end{array}$ & 3.00 & 4.00 \\
\hline Dart & 2004 & $\begin{array}{l}\text { Cross-sectional and cross-national studies focused on political } \\
\text { ideology and social enterprise. }\end{array}$ & 2.67 & 3.00 \\
\hline \multirow[t]{2}{*}{$\begin{array}{l}\text { Dempsey } \& \\
\text { Sanders }\end{array}$} & 2010 & $\begin{array}{l}\text { Understand how social entrepreneurship reinforces problematic } \\
\text { international development logics, such as by positioning local } \\
\text { groups in developing countries as the objects of intervention. }\end{array}$ & 2.67 & 3.33 \\
\hline & & $\begin{array}{l}\text { Explore the extent to ahich narratives of social entrepreneurs } \\
\text { reproduces and challenges extreme commitment, self wacrifice } \\
\text { and overwork. }\end{array}$ & 2.67 & 2.67 \\
\hline $\begin{array}{l}\text { Domenico, } \\
\text { Haugh \& } \\
\text { Tracey }\end{array}$ & 2010 & $\begin{array}{l}\text { Identify the roles that benevolence and altruism play in resource } \\
\text { acquisition. }\end{array}$ & 2.67 & 3.00 \\
\hline Dorado & 2006 & $\begin{array}{l}\text { What are the implications of the choice of govemunce forms in } \\
\text { social entrepreneurship wentures; particularly with respect to the } \\
\text { arganizations ability to remain loyal to its gocial goals? }\end{array}$ & 3.00 & 3.67 \\
\hline $\begin{array}{l}\text { Germak \& } \\
\text { Singh }\end{array}$ & 2010 & $\begin{array}{l}\text { Are social enterprises, some of which operate as forprofit } \\
\text { wentures, more or kess effective than traditional nonprofit scial } \\
\text { service programs? }\end{array}$ & 2.67 & 3.33 \\
\hline \multirow[t]{2}{*}{ Grimes: } & 2010 & $\begin{array}{l}\text { How are the various sxtors in the field of social entrepreneurship } \\
\text { (e.g. donors, govemment, academics, etc.) making sense of the } \\
\text { collective identity of social entrepreneurship? }\end{array}$ & 3.00 & 3.67 \\
\hline & & $\begin{array}{l}\text { To what exient do differences in organizational identity result in } \\
\text { differences in form and differeness in efficacy in social wentures? }\end{array}$ & 2.67 & 3.67 \\
\hline \multirow{5}{*}{$\begin{array}{l}\text { Harrik, } \\
\text { Sapienn \& } \\
\text { Bowie }\end{array}$} & 2009 & $\begin{array}{l}\text { Are founders with past traditional entrepreneurship experience } \\
\text { more likely to be successful in bunching a new social venture? }\end{array}$ & 3.33 & 4.33 \\
\hline & & $\begin{array}{l}\text { How is success measured in hybrid organirations that value both } \\
\text { soxial and cononic aims? }\end{array}$ & 2.67 & 4.00 \\
\hline & & $\begin{array}{l}\text { Under what conditions might such an explicit focus on 'purpose' } \\
\text { provide advantage for traditional entrepreneurs, versus not? }\end{array}$ & 3.67 & 3.00 \\
\hline & & $\begin{array}{l}\text { Understand the particular ethical issues endemic to social } \\
\text { entrepreneurship. }\end{array}$ & 3.00 & 2.67 \\
\hline & & $\begin{array}{l}\text { What could traditional entrepreneurs learn from the teleological, } \\
\text { purposedriven wenturing of social entrepreneurs? }\end{array}$ & 2.67 & 2.67 \\
\hline \multirow[t]{2}{*}{ Haugh } & 2005 & What is the role of social networks in identifying opportunities, & 2.67 & 4.00 \\
\hline & & $\begin{array}{l}\text { Investigate causes and consequence of social enterprise failure, } \\
\text { and identify strategies to avoid failure. }\end{array}$ & 3.00 & 3.67 \\
\hline Haugh & 2007 & $\begin{array}{l}\text { Analyze the strocture, role and contribution of social venture } \\
\text { networks, and specifically, how business information and advice } \\
\text { might be better delivered to nonprofit enterprises engaging in } \\
\text { trading activity. }\end{array}$ & 3.00 & 4.00 \\
\hline
\end{tabular}




\begin{tabular}{|c|c|c|c|c|}
\hline & & $\begin{array}{l}\text { Consider how the culture of a conprofit social venture is created, } \\
\text { the values that are distinctive to nonprofit ventures, and how those } \\
\text { values are influenced by strategies that are more frequently found } \\
\text { in for-profit ventures. }\end{array}$ & 3.00 & 3.33 \\
\hline & & $\begin{array}{l}\text { Examine bow the outcoms of social ventures are created and } \\
\text { whether standardized iechniques to evaluate and enumerate } \\
\text { outpuls and outcoms could be created. }\end{array}$ & 2.67 & 3.33 \\
\hline \multirow{4}{*}{$\begin{array}{l}\text { Kistruck \& } \\
\text { Beamish } \\
\text { Low }\end{array}$} & 2010 & $\begin{array}{l}\text { Explone how the social enterprise structure is related to specific } \\
\text { types of legitimacy (e.g. pragmatic, moral, cognitive) }\end{array}$ & 2.67 & 3.67 \\
\hline & 2006 & $\begin{array}{l}\text { Examine the change in boards of directors as noo-profits shift } \\
\text { towards for-profit forms. }\end{array}$ & 3.67 & 4.00 \\
\hline & & $\begin{array}{l}\text { Identify the dominant governance models in social enterprises and } \\
\text { investigate their effectiveness on a variety of criteria. }\end{array}$ & 3.00 & 3.67 \\
\hline & & $\begin{array}{l}\text { An examination of social enterprise bounds of directors in terms of } \\
\text { how they operate and who they elect. }\end{array}$ & 3.33 & 3.33 \\
\hline \multirow[t]{9}{*}{ Mair $\mathcal{E}$ Marti } & 2006 & $\begin{array}{l}\text { What is the link between social entrepreneurship and sustainable } \\
\text { development, and how can social entrepreneurship contribute to } \\
\text { sustainable development? }\end{array}$ & 3.33 & 4.33 \\
\hline & & $\begin{array}{l}\text { What explains the emergence of geographic clusters of social } \\
\text { entrepreneurial zctivity? }\end{array}$ & 3.00 & 4.33 \\
\hline & & $\begin{array}{l}\text { Can we observe geographical clusters with higher levels of social } \\
\text { entrepreneurial activity, e.g. India and Bangladesh, of Braxil and } \\
\text { Ecuador? }\end{array}$ & 2.67 & 4.33 \\
\hline & & $\begin{array}{l}\text { Develop useful and meaningful measures that capture the impoct } \\
\text { of social entrepreneurship and reflect the objectives pursued. }\end{array}$ & 3.00 & 4.00 \\
\hline & & $\begin{array}{l}\text { If conlext and embeddedness is so important, to what exient is it } \\
\text { possible to transfer pratices and scale cut initiatives aeross } \\
\text { geographic and community borders? }\end{array}$ & 3.00 & 4.00 \\
\hline & & $\begin{array}{l}\text { Are some forms of organizing for social entrepreneurship better } \\
\text { suited to address specific needs than others? }\end{array}$ & 2.67 & 4.00 \\
\hline & & $\begin{array}{l}\text { How does social entrepreneurship differ in developed and } \\
\text { developing countries? }\end{array}$ & 2.67 & 4.00 \\
\hline & & $\begin{array}{l}\text { Examine the embling and/or constraining effects of embeddedness } \\
\text { with regard to social entrepreneurship. }\end{array}$ & 3.00 & 3.67 \\
\hline & & $\begin{array}{l}\text { What institutional factors explain the emergence of social } \\
\text { entrepreneurship and what theonetical lenses may belp us } \\
\text { understand those factors? }\end{array}$ & 3.00 & 3.00 \\
\hline \multirow{4}{*}{$\begin{array}{l}\text { Mason, } \\
\text { Kirkbride \& } \\
\text { Eryde }\end{array}$} & 2007 & $\begin{array}{l}\text { The variables influencing legitimucy in social enterprises offer an } \\
\text { apportunity to study how governance systems facilitate an }\end{array}$ & 3.00 & 3.33 \\
\hline & & effective performance reporting process. & & \\
\hline & & $\begin{array}{l}\text { Do particular govemance arrangements have a significant impact } \\
\text { upon performance (both of the organization and individuals)? }\end{array}$ & 2.67 & 3.33 \\
\hline & & $\begin{array}{l}\text { The influesce of constitutive rules in shaping the institutional } \\
\text { environment, and usderstanding the relevarse of routines and } \\
\text { symbolic elements, would add depth to current understanding of } \\
\text { social enterprise governance. }\end{array}$ & 3.00 & 3.00 \\
\hline McDonald & 2007 & How does the organization adppt its social mission over time? & 3.33 & 2.67 \\
\hline \multirow{2}{*}{$\begin{array}{l}\text { Meyskens, } \\
\text { RobbuPost, } \\
\text { Stamp, } \\
\text { Carsnud \& } \\
\text { Reynolds }\end{array}$} & 2010 & $\begin{array}{l}\text { Investigate the presence or absence of knowledge spillover in } \\
\text { networks of social entrepreneurs. }\end{array}$ & 2.67 & 4.67 \\
\hline & & $\begin{array}{l}\text { Can social entrepreseurs position themselve to absorb knowledge } \\
\text { spillowers and transform them into competitive advantage in } \\
\text { similar ways as posited for commercial entrepreseurs? }\end{array}$ & 3.00 & 4.33 \\
\hline
\end{tabular}




\begin{tabular}{|c|c|c|c|c|}
\hline & & $\begin{array}{l}\text { Can partnerships and strategic alliances and other structures be } \\
\text { used to make the social firm more competitive and thus more } \\
\text { successful? }\end{array}$ & 2.67 & 3.00 \\
\hline & & $\begin{array}{l}\text { Does the type of social venture formation (e.g., alliances vs. } \\
\text { hierarchical governance) affect its ability to perform } \\
\text { economically? }\end{array}$ & 3.00 & 2.67 \\
\hline \multirow[t]{3}{*}{$\begin{array}{l}\text { Miller \& } \\
\text { Wesley II }\end{array}$} & 2010 & $\begin{array}{l}\text { Explore whether the increased accountability from social venture } \\
\text { capitalist funding affects performance both in the short term } \\
\text { (during funding) and long term (after funding). }\end{array}$ & 3.33 & 3.33 \\
\hline & & $\begin{array}{l}\text { Explore the longterm performance and strategic implications of } \\
\text { social venture capital funding. }\end{array}$ & 2.67 & 3.33 \\
\hline & & $\begin{array}{l}\text { Examine the structure and timing of social venture capital } \\
\text { decisions. }\end{array}$ & 3.00 & 3.00 \\
\hline \multirow[t]{2}{*}{$\begin{array}{l}\text { Munoz \& } \\
\text { Tinsley }\end{array}$} & 2008 & $\begin{array}{l}\text { Examine the degree to which social enterprises are emerging in } \\
\text { response to public-sector demand and the implications this has for } \\
\text { the autonomy of social enterprise as something separate from the } \\
\text { state. }\end{array}$ & 3.33 & 3.33 \\
\hline & & $\begin{array}{l}\text { Explore the evolution of the relationship between social enterprise } \\
\text { and the public sector. }\end{array}$ & 2.67 & 2.67 \\
\hline $\begin{array}{l}\text { Murphy \& } \\
\text { Coombs }\end{array}$ & 2009 & $\begin{array}{l}\text { Do social purposes change over time (either in direction or } \\
\text { strength)? }\end{array}$ & 3.00 & 3.33 \\
\hline $\begin{array}{l}\text { Peredo \& } \\
\text { Chrisman }\end{array}$ & 2006 & $\begin{array}{l}\text { May community-based enterprises be effectively introduced in } \\
\text { communities (e.g., in refugee settings) that do not have a shared } \\
\text { history of cooperative effort? }\end{array}$ & 3.33 & 2.67 \\
\hline \multirow[t]{13}{*}{$\begin{array}{l}\text { Sbort, Moss \& } \\
\text { Lumpkin }\end{array}$} & 2009 & $\begin{array}{l}\text { Which dimensions of an entrepreneurial orientation are key to } \\
\text { effective social venturing? }\end{array}$ & 2.67 & 5.00 \\
\hline & & $\begin{array}{l}\text { Can social entrepreneurs create disruptive innovations in the } \\
\text { commercial sector? }\end{array}$ & 3.00 & 4.33 \\
\hline & & $\begin{array}{l}\text { What strategic and managerial consequences flow from social } \\
\text { entrepreneurs' urge to satisfy both economic and social objectives? }\end{array}$ & 2.67 & 4.33 \\
\hline & & $\begin{array}{l}\text { Is there a difference in the meaning and function of social } \\
\text { entrepreneurship across cultural boundaries? }\end{array}$ & 3.33 & 3.67 \\
\hline & & $\begin{array}{l}\text { Which entrepreneurial and strategic processes are most effective } \\
\text { for creating social value across different social entrepreneurship } \\
\text { activities? }\end{array}$ & 3.33 & 3.33 \\
\hline & & $\begin{array}{l}\text { In what ways to social innovation processes change the ventures } \\
\text { creating the innovations? }\end{array}$ & 3.33 & 3.33 \\
\hline & & $\begin{array}{l}\text { Do social ventures hold more conservative stances toward risk } \\
\text { than commercial ventures? }\end{array}$ & 2.67 & 3.33 \\
\hline & & $\begin{array}{l}\text { In what ways do technologies provide competitive advantages in } \\
\text { social ventures? }\end{array}$ & 2.67 & 3.33 \\
\hline & & $\begin{array}{l}\text { How can social entrepreneurship activities be measured to enable } \\
\text { economic analysis? }\end{array}$ & 2.67 & 3.33 \\
\hline & & $\begin{array}{l}\text { Are the motivations/drivers of social venture creation the same as } \\
\text { or different from those of traditional venture creation? }\end{array}$ & 3.00 & 3.00 \\
\hline & & What factors most impact social innovation diffusion? & 3.00 & 3.00 \\
\hline & & $\begin{array}{l}\text { Does the unique experience of a social venture foster the creation } \\
\text { of new opportunities? }\end{array}$ & 2.67 & 3.00 \\
\hline & & $\begin{array}{l}\text { Do social entrepreneurs use opportunity discovery processes in the } \\
\text { same ways as commercial entrepreneurs? }\end{array}$ & 2.67 & 3.00 \\
\hline \multirow[t]{2}{*}{$\begin{array}{l}\text { Young \& } \\
\text { Tilley }\end{array}$} & 2006 & $\begin{array}{l}\text { Are best practices of sustainable entrepreneurship transferable } \\
\text { between organizations? }\end{array}$ & 3.00 & 3.33 \\
\hline & & Is sustainable entrepreneurship measurable? & 2.67 & 3.00 \\
\hline $\begin{array}{l}\text { Zahra, } \\
\text { Rawhouser, }\end{array}$ & 2008 & $\begin{array}{l}\text { What are the personal or structural factors that contribute to social } \\
\text { ventures' emergence, organizing behavior, and subsequent }\end{array}$ & 3.33 & 4.00 \\
\hline
\end{tabular}

Bhawe, successes and failures?

Neubaum \&

Hayton

Given that behavioral theory argues that entrepreneurs satisfice when confronted with multiple constrains, does the increased complexity of multiple stakeholders influence the decisions of entrepreneurs?

Does the globalization of social ventures' missions slow down entrepreneurs' decision-making process?

*The full list of 327 topics bas been made available at: http://www.SocEntResearch.org

†AIS: "Average Interesting Score" is the average rating given by the subject matter experts when asked the following question: "In your opinion, how interesting is the [topic]?"

\$ADS: "Average Development Score" is the average rating given by the subject matter experts when asked the following question: "In your opinion, how well does the [topic] lend itself to theoretical development and/or empirical analysis?" 